\title{
Cash Flow Statement Analysis between Commercial Banks (With Reference to Himalayan Bank Ltd. and Global IME Bank Ltd.)
}

\author{
Lilaballabh Dhakal \\ Butwal Multiple Campus, Butwal, Nepal \\ Email:dhakallila@gmail.com
}

How to cite this paper: Dhakal, L. (2019) Cash Flow Statement Analysis between Commercial Banks (With Reference to Himalayan Bank Ltd. and Global IME Bank Ltd.). American Journal of Industrial and Business Management, 9, 2025-2033. https://doi.org/10.4236/ajibm.2019.911133

Received: July 27, 2019

Accepted: November 24, 2019

Published: November 27, 2019

Copyright () 2019 by author(s) and Scientific Research Publishing Inc. This work is licensed under the Creative Commons Attribution International License (CC BY 4.0).

http://creativecommons.org/licenses/by/4.0/ (c) (i) Open Access

\begin{abstract}
Banks are general means of institutions that deal with money. They provide financial resources for the development of the nation. They collect deposits from the people and lend these resources to people who demand investment. This study aims to evaluate and compare cash flows of selected two commercial banks. It helps to find out sources and uses of cash to analyze cash flow performance of Himalayan Bank and Global IME Bank limited. Cash flow statement is a statement which states the cash inflows and outflows of cash. A statement of cash flow reports cash receipts and payments classified according to the major activities: operating, investing and financing during the period. In this paper, a comparative study has been undertaken between two banks Global IME Bank limited and Himalayan Bank Limited. This study has been carried out with analytical research design to analyze the cash flow of two banks. Secondary data were used in this study. The cash flow from operating, investing and financing activities is fluctuating trend. It is also found that operating cash flow is positive and financing cash flow is negative in most of the years. In comparison, the cash flow of HBL has more consistency than GIBL. Both banks have positive Net cash flow except few years. Because of the conflict and political instability, the banking sector has also been affected. In banking industry, it seems that operating expenses are increasing year by year. Therefore, commercial banks should pay good attention to the minimization of operating expenses as possible.
\end{abstract}

\section{Keywords}

Cash flow analysis, Operating Activities, Investing Activities, Financing Activities, Cash Equivalent, Cash Management 


\section{Introduction}

Bank is a financial institution that accepts deposit from public and lending them who shall be needed. Banks help to the grooming of economics activities. Development of the nation depends upon the development and enhancement of economic activities. Economic growth and its distribution among the people lead to the creation of equitable society in the nation. Banks provide economic resources required for the development of industries, trade and agriculture. They are considered as one of the major sources of economy. They do several economic and financial activities in the nation. But in our context, most of them are not operating well. They are suffering from various problems directly and indirectly.

Even before the establishment of banking institution in Nepal, financial transaction was in practices as undertaken by some moneylenders like goldsmith, Sahu-Mahajan \& Jamindar. Although they were not an organized manner, these activities were not directed towards the economic goal or mission of the nation. Hence, to meet the growing need of nation economy, Nepal bank Ltd. came into existence in 1937 as the first commercial bank of Nepal even before the establishment of Nepal Rastra Bank.

Nepal Bank Ltd. had been started the act of consolidating the scattered capital since its establishment in order to mobilize in productive sector. It developed a systematics tradition and culture of modern banking system in Nepal. Such system could able to establish a strong base to uplift the national economy. In 1956, Nepal Rastra Bank was established under Nepal Rastra Bank act 1955.

Nepal Rastra Bank plays the most important role in different sectors. It helps to mobilize capital or fund for development and encourages trade and industrial sector for enhancement. It provides financial security as well as valuable instructions to commercial banks and other related sectors. Therefore, it is more essential to the development of banking system and regulation of financial activities in the government of Nepal. Now commercial banks are operated under the directive of NRB and NRB Act 2058. There is also existence of Bank and Financial Institution Act (BAFIA) to operate commercial bank on the new climate. After the liberalization in the decade of 2050, various commercial banks started to provide the service in the field of financial sector of the country. A number of finance companies and saving and credit co-operative institutions have been established to provide financial service to the country.

Cash flow statement is the systematic and analytical presentation of inflow and outflow of cash flow from different sources within an accounting period. It is the reconciliation of opening and closing cash. The FASB no 95 "statement of cash flow" issued in 1987 has classified the cash flow into operating activities, investing activities and financing activities. Similarly, Nepal accounting standard issued by NASB (2003) cash flow statement should report cash flow during the period classified by operating activities, investing activities and financing activities.

Himalayan Bank Limited (HBL) is one of the largest private banks in Nepal. The Bank was incorporated in 1993 by a few eminent individuals of Nepal in 
partnership with the Employees Provident Fund and Habib Bank Limited of Pakistan. The bank commenced its operations in January 1993. Himalayan Bank is also the first commercial bank of Nepal with most of its shares held by the private sector of Nepal. Besides commercial banking services, the bank also offers industrial and merchant banking service. The paid-up capital of the bank has since been increased to NPR 8.11 billion. The bank's shares are publicly traded as an "A" category company in the Nepal Stock Exchange (Himalayan Bank Limited (2010/11 to $2017 / 18)$ [1].

Global IME Bank Ltd. (GIBL) emerged after successful merger of Global Bank Ltd (an "A" class commercial bank), IME Financial Institution (a " $\mathrm{C}$ ” class finance company) and Lord Buddha Finance Ltd. (a "C" class finance company) in year 2012. Two more development banks (Social Development Bank and Gulmi Bikas Bank) merged with Global IME Bank Ltd in year 2013. Later, in the year 2014, Global IME Bank made another merger with Commerz and Trust Bank Nepal Ltd. (an "A” class commercial bank). Global Bank Limited (GBL) was established in 2007 as an "A" class commercial bank in Nepal which provided entire commercial banking services. The bank was established with the largest capital base at the time with paid-up capital of NPR 1.0 billion. The paid-up capital of the bank has since been increased to NPR 10.31 billion. The bank's shares are publicly traded as an "A" category company in the Nepal Stock Exchange (Global IME Bank Limited (2010/11 to 2017/18) [2].

\subsection{Statement of the Problem}

Being the reputed banking institution and having almost similar organization structure and objectives, the banks are not earning the same amount of profit, cash flows and not able to meet the return on cash basis on equal term and the share prices of these banks are different too. Rules and regulation, as well as directives imposed by government and NRB provide both opportunity and threat to the commercial banks operating in the country.

The main problems of these commercial banks are mentioned below:

- What is the position of cash flow from operating, financing and investing activities?

- What is the condition of cash flow with the highest amount of annual operating profit?

- What does their cash flow indicate? Is the cash managed properly or not?

\subsection{Objectives of the Study}

The main objective of this study is to know about the cash flow analysis and its management in commercial bank of Nepal. This study helps to evaluate and compare cash flow statement of the selected Commercial banks. The specific objectives are as follows:

To find out the sources and uses of cash.

To measure the sources and uses of cash against profit position. 
To compare and analyze the cash flow performance of Himalayan Bank and Global IME Bank Ltd.

\section{Review of Literature}

The meaning of cash flows is the inflow and outflow of cash and cash equivalent in the organization. The purpose of the cash flow statement is to provide the information to the management about cash receipt and payment of an organization and it's used in efficient cash management. Different writers have published their books and articles expressing importance and uses of cash flow statement and some of their views are presented below:

Koirala, et al. (2014) maintain in their book, In United States, the cash flow statement has been necessary to submit along with balance sheet and income statement since 1988. In 1992, British, Australia, New Zealand and South Africa are also required to publish cash flow statement. The company act 2063 also required Nepalese companies to present cash flow statement along with balance sheet and income statement. Therefore every organization has to prepare it's as an integral part of financial statements for the period for which financial statement are presented [3].

Munakami (2002) wrote a book. In his book, a cash flow statement is a statement of company's ability to generate cash from various activities such as operating, investing and financing and their needs of cash. It is a statement that shows the inflows and outflows of cash and cash equivalents during the year. Recognizing the importance and usefulness of cash flow analysis, the FASB (Financial Accounting Standards Board) issued [4].

Dangol, et al. (2011) wrote a book. In their book, a cash flow statement is useful its plan financial operation in an efficient manner. A cash flow statement is the total of cash flow from operating, investing and financing activities. Cash flows statement shows cash inflow, outflow and ending position by interim period for a special time period [5].

Koirala, et al. (2014) [3], Munakami, S.P. (2002) [4] and Dangol, R.M. (2011) [5] wrote different books. In their books, they described the necessary of cash flow statement, its publication and to submit the cash flow statement along with income statement and balance sheet to the organization. They wrote on necessity and when, how and why should it be prepared and submitted to the organization. But this research work is directed to find out sources and uses of cash, to evaluate and compare the cash flow statement of selected commercial banks.

\section{Research Methodology}

This study has been carried out with descriptive as well as analytical research design to analyze the financial performance of the selected Commercial banks. Various financial parameters and effective research techniques are applied. The data employed in the study are from secondary sources \& to some extent primary source data is also included. The audited Balance Sheet, profit \& loss A/C, 
Cash Flow Statement and related schedules of the concerned commercial Banks are collected. Besides these, other essential data and information have been collected from some published and unpublished documents (Adhikari, R., 2010) [6].

\section{Results and Findings}

It is the process of organization the data by tabulating and then placing that data in presentable form by using various tables. The main purpose of this study is to assess the comparative cash flow management of selected two commercial banks.

\subsection{Cash Flow from Operating Activities}

The cash flow from operating activities of the banks includes the receipts, payments and affecting current assets and current liabilities. Cash Flow from Operating Activities mainly focuses on the cash inflows and outflows from a company's main business activities of buying and selling merchandise, providing services, etc. Cash flow from operating activities includes the cash collection from debtors, depreciation, interest received, payment to creditors and others operating expenses, payment for interest, tax and dividend, and so on (Bajarcharya, P., et al., 2012 and Gupta, S.P., 1992) [7] [8]. They are similar in most of aspect in the angle of socio-economic development of the nation.

Table 1 shows the amount of Cash Flow from Operating Activities. Banks have negative cash flow in one fiscal year and two fiscal years among eight years of Himalayan Bank and Global IME Bank respectively. Himalayan Bank has strong CFOA than Global IME bank in three fiscal year i.e. 2010/11, 2012/13 \& 2014/15 and remaining FY Global IME Bank CFOA is strong than Himalayan Bank. HBL CFOA changing ratio is less fluctuating than GIBL. HBL \& GIBL have maximum changing ratio and minimum changing ratio are $207.92 \%, 3814.3 \%$ and $-244.64 \%,-107.50 \%$ respectively. HBL has more

Table 1. Cash flow from operating activities.

\begin{tabular}{|c|c|c|c|c|}
\hline \multirow{2}{*}{ Years } & \multicolumn{2}{|c|}{ Himalayan Bank } & \multicolumn{2}{|c|}{ Global IME Bank } \\
\hline & CFOA & $\%$ Change & CFOA & $\%$ Change \\
\hline $2010 / 11$ & 1229.72 & - & $(807.75)$ & - \\
\hline $2011 / 12$ & 1195.10 & $-2.81 \%$ & $2,465.90$ & $405.28 \%$ \\
\hline $2012 / 13$ & 1489.62 & $24.64 \%$ & 53.43 & $-77.56 \%$ \\
\hline $2013 / 14$ & 1355.85 & $-8.98 \%$ & $2,797.17$ & $405.43 \%$ \\
\hline $2014 / 15$ & 1110.86 & $-18.07 \%$ & (209.83) & $-107.50 \%$ \\
\hline $2015 / 16$ & 3420.62 & $207.92 \%$ & $7,793.72$ & $3814.3 \%$ \\
\hline $2016 / 17$ & $(4947.66)$ & $-244.64 \%$ & $7,287.72$ & $-6.49 \%$ \\
\hline $2017 / 18$ & 1081.39 & $121.86 \%$ & $5,575.12$ & $-23.49 \%$ \\
\hline
\end{tabular}

Source: Himalayan Bank and Global IME Bank (FY 2010-2011 to FY 2017-2018). 
consistency than GIBL and GIBL has high Fluctuation.

\subsection{Cash Flow from Investing Activities}

Cash flow from investing activities indicates how much money has been used in making investments in a specific time period. It collects money as deposit and sells for the customer, which called, investment. Investment may be in terms of bank balance, money at call and short notice, loan, fixed assets or other assets, purchase or sale of assets, payment-related merger and acquisition and so on (Bajarcharya, P., et al., 2012 and Gupta, S.P., 1992) [7] [8]. Cash flow from investing activities of selected two commercial banks is tabulated as follows.

Table 2 shows cash flow from investing activities of Himalayan Bank and Global IME Bank. Which has shown negative CFIA except for two FY. Negative Cash flow from investing activities indicates that purchases of long-term assets such as property, plant and equipment and acquisitions of other businesses and investments in stocks and bonds. HBL CFIA changing ratio is less fluctuation than GIBL. HBL \& GIBL has maximum changing ratios and minimum changing ratios are $1146.42 \%, 22,579.21 \%$ and $-228.10 \%,-507.23 \%$ respectively. HBL has more consistency than GIBL and GIBL has high Fluctuation.

Table 2. Cash flow from investing activities.

Amounts in million

\begin{tabular}{ccccc}
\hline \multirow{2}{*}{ Years } & \multicolumn{2}{c}{ Himalayan Bank } & \multicolumn{2}{c}{ Global IME Bank } \\
\cline { 2 - 4 } & CFIA & \% Change & CFIA & \% Change \\
\hline $2010 / 11$ & $(138.74)$ & - & 166.00 & $307.93 \%$ \\
$2011 / 12$ & $(1729.28)$ & $1146.42 \%$ & $(345.16)$ & $-96.35 \%$ \\
$2012 / 13$ & $(1765.44)$ & $2.09 \%$ & $(12.60)$ & $22,579.21 \%$ \\
$2013 / 14$ & $(6713.75)$ & $280.29 \%$ & $(2857.58)$ & $-79.47 \%$ \\
$2014 / 15$ & 2347.46 & $-134.96 \%$ & $(586.79)$ & $1064.46 \%$ \\
$2015 / 16$ & $(3521.21)$ & $-250 \%$ & $(6832.96)$ & $122.14 \%$ \\
$2016 / 17$ & 1270.65 & $136.08 \%$ & 1513.17 & $-507.23 \%$ \\
$2017 / 18$ & $(1627.73)$ & $-228.10 \%$ & $(6162.04)$ & \\
\hline
\end{tabular}

Source: Himalayan Bank and Global IME Bank (FY 2010-2011 to FY 2017-2018).

\subsection{Cash Flow from Financing Activities}

Financing means raising capital through issuing share, debenture and bond and also taking soft loan from NRB. Inflow of cash from financial activities represents issue of share, debenture, bond and taking loan from NRB and outflow of cash from financial activities represents return of debenture, bond, soft loan of NRB, interest in loan, debenture, bond and also the payment of dividend to its shareholders. Cash flow from financing activities provides investors with insight into a company's financial strength and how well a company's capital structure is managed (Bajarcharya, P., et al., 2012 and Gupta, S.P., 1992) [7] [8] Cash flow 
from financing activities of selected commercial banks is tabulated as follows.

Table 3 shows that HBL has negative cash flow from financing activities except for the two FY i.e. 2012/13 and 2016/17. GIBL has positive cash flow from financing activities in four FY and has negative cash flow from financing activities in the rest four years. Negative cash flow from investing activities shows that more financing from debt, equity, and dividends. As per above table, HBL is comparatively more financing than GIBL. HBL CFFA changing ratio is less fluctuation than GIBL. HBL \& GIBL hve maximum changing ratio and minimum changing ratio are $243.75 \%, 12,382.7 \%$ and $-188.07 \%,-2988.23 \%$ respectively. HBL and GIBL have high Fluctuation trend.

Table 3. Cash flow from financing activities.

\begin{tabular}{|c|c|c|c|c|}
\hline \multirow{2}{*}{ Years } & \multicolumn{2}{|c|}{ Himalayan Bank } & \multicolumn{2}{|c|}{ Global IME Bank } \\
\hline & CFFA & \% Change & CFFA & $\%$ Change \\
\hline $2010 / 11$ & (225.05) & - & (38.14) & - \\
\hline $2011 / 12$ & $(379.22)$ & $68.50 \%$ & 1101.57 & $-2988.23 \%$ \\
\hline $2012 / 13$ & 333.99 & $-188.07 \%$ & 26.39 & $-97.6 \%$ \\
\hline $2013 / 14$ & $(426.98)$ & $227.84 \%$ & $(22.78)$ & $186.32 \%$ \\
\hline $2014 / 15$ & $(613.50)$ & $43.68 \%$ & 80.07 & $-451.49 \%$ \\
\hline $2015 / 16$ & $(411.844)$ & $32.87 \%$ & $(11.75)$ & $-114.67 \%$ \\
\hline $2016 / 17$ & 592.04 & $243.75 \%$ & 1443.22 & $12,382.7 \%$ \\
\hline $2017 / 18$ & (122.93) & $-120.76 \%$ & $(839.87)$ & $-158.19 \%$ \\
\hline
\end{tabular}

Source: Himalayan Bank and Global IME Bank (FY 2010-2011 to FY 2017-2018).

\subsection{Net Change in Cash Flow}

The net cash flow of the bank is the summation of cash flow from operating, cash flow from investing and cash flow from financing activities. It shows the cash surplus or deficit of the banks under study in different fiscal years. They use cash for payroll, asset purchases and many other purposes. The net change in cash is the amount by which a company's cash balance increases or decreases in a fiscal period. Net change in Cash flow of selected commercial banks is tabulated as follows.

Table 4 shows that HBL has positive net change in cash flow from FY second, fourth \& fifth and remaining FY has negative. GIBL has positive net change in cash flow except first, fifth and last FY year. Positive net change in cash flow shows company's cash balance increases. HBL has comparatively less fluctuation than GIBL. Similarly, HBL and GIBL have maximum and minimum changing ratios are $476.75 \%, 944.11 \%$ and $-502.04 \%,-125.13 \%$ respectively.

\subsection{Findings}

HBL CFOA changing ratio is less fluctuation than GIBL. HBL \& GIBL have 
Table 4. Net change in cash flow.

Amounts in million

\begin{tabular}{lcccc}
\hline \multirow{2}{*}{ Years } & \multicolumn{2}{c}{ Himalayan Bank } & \multicolumn{2}{c}{ Global IME Bank } \\
\cline { 2 - 5 } & Cash Flow & $\%$ Change & Cash Flow & \% Change \\
\hline $2010 / 11$ & $(901.84)$ & - & $(679.89)$ & - \\
$2011 / 12$ & 3397.64 & $476.75 \%$ & 3222.32 & $573.95 \%$ \\
$2012 / 13$ & $(2714.10)$ & $-179.88 \%$ & 567.22 & $-82.40 \%$ \\
$2013 / 14$ & 1894.39 & $169.80 \%$ & 2711.14 & $377.97 \%$ \\
$2014 / 15$ & 2844.82 & $50.17 \%$ & $(681.28)$ & $-125.13 \%$ \\
$2015 / 16$ & $(512.42)$ & $-118.01 \%$ & 985.83 & $44.70 \%$ \\
$2016 / 17$ & $(3084.97)$ & $-502.04 \%$ & $10,293.19$ & $944.11 \%$ \\
$2017 / 18$ & $(669.275)$ & $78.30 \%$ & $(1426.80)$ & $-86.14 \%$ \\
\hline
\end{tabular}

Source: Himalayan Bank and Global IME Bank (FY 2010-2011 to FY 2017-2018).

maximum changing ratio and minimum changing ratio are $207.92 \%, 3814.3 \%$ and $-244.64 \%,-107.50 \%$ respectively. HBL has more consistency than GIBL and GIBL has high Fluctuation. HBL CFIA changing ratio is less fluctuation than GIBL. HBL \& GIBL have maximum changing ratio and minimum changing ratio are $1146.42 \%, 22,579.21 \%$ and $-228.10 \%,-507.23 \%$ respectively. HBL has more consistency than GIBL and GIBL has high Fluctuation. HBL CFFA changing ratio is less fluctuation than GIBL, HBL \& GIBL has maximum changing ratio and minimum changing ratio are $243.75 \%, 12,382.7 \%$ and $-188.07 \%$, $-2988.23 \%$ respectively. HBL and GIBL have high Fluctuation trend.HBL Net Change in cash flow changing ratio is less fluctuation than GIBL, HBL \& GIBL has maximum changing ratio and minimum changing ratio are $476.75 \%$, $944.11 \%$ and $-502.04 \%,-125.13 \%$ respectively. HBL and GIBL have high Fluctuation trend.

\section{Conclusions}

Nowaday's cash flow statement is being mandatory to submit for annual report and cash flow is being a key financial indicator to analyze the strength and weakness of the organization. Profit made under accrual basis does not provide the real figure of the organization so income should be treated of cash basis according to the NRB directive for financial institution. Stakeholders believe the institution if cash flow is positive irrespective of profit whether it is positive or negative. Positive flow of cash is very much important and base for any institution's smooth operation. It does not matter how much profit an institution earned if it does not have liquidity for its daily operation. So cash flow analysis is the most important condition. By analyzing the five-year cash flow statement, following conclusion was found and recommended for improvement.

Now in the context of Nepalese economy joint venture, commercial banks have good performance in the highly comparative market. Because of the con- 
flict and instability of political situation and entire economic sector, banking sector also had been affected. Operating cash flow is positive in most of the year but the trend is fluctuating. So bank should launch new sector to enhance this source. Source of investment should be identified to earn significant amount of interest.

The main source of operating cash flow is interest income and main source of interest is loan and advance so they are increased less than deposits, so new area of investment should be found out. Office and staff expenses restrict to earn the highest operating profit. The bank has good public faith so deposits are increasing but the bank has to manage its deposit by reducing interest bearing deposits. Due to the strong worldwide networking, fund transfer is accessible so it should be managed properly. Operating cash flow is positive but financial cash flow is negative in most of the years. One of the main problems of the banks is increasing staff and operating cost. It should be minimized.

\section{Conflicts of Interest}

The author declares no conflicts of interest regarding the publication of this paper.

\section{References}

[1] Himalayan Bank Limited (2010/11 to 2017/18) Annual Reports. Kathmandu.

[2] Global IME Bank Limited (2010/11 to 2017/18) Annual Reports. Kathmandu.

[3] Koirala, et al. (2014) Management Accounting. $3^{\text {rd }}$ Edition, Buddha Academic Publishers and Distributors Pvt, Kathmandu.

[4] Munakami, S.P. (2002) Management Accounting. Buddha Academic Publisher and Distributors, Kathmandu.

[5] Dangol, R.M. (2011) Management Accounting. $5^{\text {th }}$ Edition, Taleju Parkashan, Kathmandu.

[6] Adhikari, R. (2010) Research Methodology. Januka Prakashan, Kathmandu.

[7] Bajarcharya, P., et al. (2012) Management Accounting. Asmita Books Publishers \& Distributors, Kathmandu.

[8] Gupta, S.P. (1992) Management Accounting. $2^{\text {nd }}$ Edition, Agra Sahitya Bhandar, Kathmandu. 